\title{
Poultry Effluent Bio-treatment with Spirodela intermedia and Periphyton in Mesocosms with Water Recirculation
}

\author{
Gabriel Basílico • Laura de Cabo • Anahí Magdaleno • \\ Ana Faggi
}

Received: 12 February 2016 / Accepted: 16 May 2016

(C) Springer International Publishing Switzerland 2016

\begin{abstract}
Industrial production of poultry meat is associated with indirect environmental impacts such as contributing to climate change and deforestation and other direct impacts such as the deterioration of the quality of surface waters. Poultry industry effluents are rich in organic matter, nitrogen, and phosphorus; nutrients can be removed from wastewater through the use of macrophytes and periphyton. An essay in mesocosms with poultry industry wastewater recirculation was developed in the presence and absence of a native macrophyte Spirodela intermedia and periphyton from a lowland stream (La Choza stream, Buenos Aires) where the effluent is poured. The diffusion of $\mathrm{O}_{2}$, increased by water recirculation, had the effect of increasing the concentration of dissolved oxygen in wastewater. The presence of $S$. intermedia and algae periphyton significantly contributed to the removal rates (\%) of solids $(69.7 \pm 3.9)$, ammonium nitrogen $(84.0 \pm 3.4)$, and total
\end{abstract}

G. Basílico $(\bowtie) \cdot$ L. de Cabo · A. Faggi

Museo Argentino de Ciencias Naturales "Bernardino Rivadavia", Consejo Nacional de Investigaciones Científicas y Técnicas, Av. Ángel Gallardo 470, C1405DJR Ciudad Autónoma de Buenos Aires, Argentina

e-mail: gabrielomarbasilico@hotmail.com

G. Basílico · L. de Cabo · A. Faggi

Laboratorio de Bioindicadores y Remediación, Universidad de Flores, Bacacay 2932, C1406GEB Ciudad Autónoma de Buenos Aires, Argentina

A. Magdaleno

Facultad de Farmacia y Bioquímica, Universidad de Buenos Aires, Junín 954, C1113AAD Ciudad Autónoma de Buenos Aires, Argentina phosphorus (38.1 \pm 1.8$)$ from residual water and favored nitrification. The dominance of Bacillariophyceae on other groups of algae of periphyton and the low representation of Euglenophyceae indicated an advanced stage of the effluent treatment process at the end of the assay.

Keywords Wastewater - Nutrients · Phytoremediation . Duckweed · Biofilms

\section{Introduction}

The production of poultry meat is increasing largely at the global scale because of its low cost and its increasing per capita demand in Asia and other regions; thus, in the coming decades, it is expected that small-scale production will be replaced by intensive industrial farming systems under the control of large companies (Sharma 2014). These production systems are seriously questioned from the point of view of animal welfare because of widespread bone problems among birds, like osteoporosis and fractures, deprivation of natural behaviors caused by breeding cages, pecking and feather loss, or high levels of stress due to improper handling during transport and slaughter, among others (Nicol and Davies 2013). In addition, intensive meat production has a negative impact on natural environments, such as deforestation of vast areas for the cultivation of forage and grain or high demand for fresh water, fertilization excess, erosion, loss of biodiversity, and the contribution 
of greenhouse gases that contribute to climate change (Benning 2014).

Another problem arising directly from intensive poultry production is the contamination of surface water, with effects on water quality in the environments receiving effluents, such as increased concentrations of organic matter and nutrients (Basílico et al. 2015), particularly when the wastewater pretreatment is insufficient to meet the discharge requirements (Yetilmezsoy and Sapci-Zengin 2009). The dynamics of nitrogen and phosphorus in surface water and its compartmentalization in the water column and sediment is markedly different. Nitrogen is assimilated by algae and macrophytes as nitrate and ammonium and it is generally found in highest concentrations in water column than in sediments (Lewis and Wang 1997). Ammonia comes mainly from bacterial degradation of organic nitrogen compounds contained in waste discharges. The conversion of ammonium to nitrite and nitrate (nitrification) is a very important natural process in ammonia removal from wastewater. This is a two-step sequencing biological oxidation process consisting in (1) the oxidation of ammonium to nitrite, carried out by ammoniumoxidizing bacteria (AOB), and (2) the following oxidation of nitrite to nitrate, carried out by nitrite-oxidizing bacteria (NOB) (Ge et al. 2015). Basílico et al. (2013) and Finnegan et al. (2009) observed a rapid conversion of ammonium to nitrite and nitrate in static systems treatment and continuous flow, respectively. Otherwise, the concentration of phosphorus is the result of a balance between the dissolved fraction (soluble reactive phosphorus, SRP) and the adsorbed phosphorus to the sediments, which in relative terms is much higher (Lewis and Wang 1997).

Aquatic plants have an important role in the ecology of rivers, lakes, and estuaries, serving as food and refuge to species of higher trophic levels, providing oxygen to the water and as a fundamental part of the biogeochemical cycles of nitrogen and phosphorus, fulfilling a key role in the processes of self-purification of lowland rivers and streams (Levi et al. 2015). This group of organisms includes species of phytoplankton and periphyton algae and submerged, floating, and emergent macrophytes. The ability of some species of algae and macrophytes to accumulate contaminants and nutrients in roots, stems, and other tissues can be exploited to reduce the levels of metals, phenols, BOD, COD, solids, alkalinity, acidity, hardness, and coliform bacteria in water, in both natural environments and alternative systems of sewage treatment, which also tend to have a lower cost compared to conventional treatments (Mohan and Hosetti 1999). The removal of nutrients by macrophytes is affected by various factors such as potential toxicity of the wastewater (Salminen et al. 2001). On the other hand, some species of algae have the ability to accumulate metals in the interior of the cell through the synthesis of metallothioneins (Gekeler et al. 1988), the formation of vacuolar complexes (Heuillet et al. 1986), or incorporation in chloroplasts (MendozaCózatl and Moreno-Sánchez 2005) and mitochondria (Avilés et al. 2003).

The Lemnaceae family is characterized by tiny floating macrophytes and includes about 40 species worldwide (Mohan and Hosetti 1999). Some species of this family have a proven ability to improve the quality of wastewater by removing nutrients (Srivastava et al. 2008) and are easily harvestable. Spirodela polyrrhiza has been used, for example, in phytoremediation and nutrient recovery experiences (Xu and Shen 2011). The species Spirodela intermedia has been little studied; it is distributed in South and Central America (Mazzeo 1993), in particular, in water bodies of the Pampas (Argentina) (Feijoó and Lombardo 2007) where it was selected as a potential candidate for the remediation of effluents from the poultry industry (Basílico et al. 2013).

The group of organisms that grow on submerged objects is generically designated as periphyton and includes bacteria, protozoa, rotifers, and attached algae and other microorganisms. The structural and functional characteristics of periphyton communities reflect the water quality and can be used as biological indicators (APHA, AWWA and WPCF 1992). Periphyton algae have an important role in the metabolism of low order watercourses (Vilches and Giorgi 2010) and are important components of the biogeochemical cycles of nitrogen (Levi et al. 2015) and, particularly, phosphorus (Feijoó et al. 2011) in lowland streams. The absorption and adsorption of organic detritus, nitrogen, and phosphorus by periphyton biomass allow the use of these communities in wastewater treatment (Wu et al. 2014). On the other hand, significant simultaneous removal of nitrogen and phosphorus dissolved by periphyton in wastewater treatment and recommended application to post-treatment of municipal water has been described by Boelee et al. (2011). The possibility of separating and harvesting algal periphyton biomass is an advantage over the use of planktonic algae, favoring the recovery of nutrients (Wilkie and Mulbry 2002). 
The objectives of this study were to evaluate the feasibility of remediation of poultry wastewater by utilizing a macrophyte species $S$. intermedia at lab-scale reactors with continuous recirculation of water and to assess the contribution of periphyton in this process.

\section{Materials and Methods}

\subsection{Poultry Wastewater Sampling}

Approximately 701 of poultry effluent were collected. This wastewater is poured into La Choza stream ( $34^{\circ} 39^{\prime}$ 48.64" S, 58 56' 44.43" W, district of General Rodriguez, Buenos Aires) by a poultry industry through an open channel. The effluent was characterized by Basílico et al. (2013). It has a slightly alkaline $\mathrm{pH}$ $(7.48 \pm 0.40)$, electrical conductivity (EC) of 1.33 $\pm 0.04 \mathrm{mS} / \mathrm{cm}$, low dissolved oxygen content $(\mathrm{OD}=0.4 \pm 0.8 \mathrm{mg} / \mathrm{l})$, a high load of organic matter (BOD5 $=197 \pm 19 \mathrm{mg} / \mathrm{l}$ ), and high concentrations of total suspended solids (TSS $=198 \pm 39 \mathrm{mg} / \mathrm{l})$, ammonium nitrogen $\left(\mathrm{NH}_{4}{ }^{+}-\mathrm{N}=21.27 \pm 4.36 \mathrm{mg} / \mathrm{l}\right)$, SRP (3.5 $\pm 1.0 \mathrm{mg} / \mathrm{l})$, total phosphorus $(\mathrm{TP}=5.8 \pm 0.9 \mathrm{mg} / \mathrm{l})$, and total organic carbon $(\mathrm{TOC}=121 \pm 41 \mathrm{mg} / \mathrm{l})$ compared to concentrations found in the receiving water body (Basílico et al. 2013).

\subsection{Analytical Procedures}

In wastewater samples were determined $\mathrm{pH}, \mathrm{EC}$, and DO with HANNA ${ }^{\circledR}$ sensors, TSS (APHA, AWWA and WPCF 1992), alkalinity $\left(\mathrm{HCO}_{3}{ }^{-}\right), \mathrm{NH}_{4}{ }^{+}-\mathrm{N}$ (Mackereth et al. 1989), nitrites $\left(\mathrm{NO}_{2}{ }^{-}-\mathrm{N}\right)$, nitrate $\left(\mathrm{NO}_{3}{ }^{-} \mathrm{N}\right)$, SRP, TP (Strickland and Parsons 1972), TOC, dissolved, and particulate organic carbon (DOC and POC, respectively) (Golterman et al. 1978). The concentration of dissolved inorganic nitrogen was calculated as the sum of $\mathrm{NH}_{4}{ }^{+}-\mathrm{N}, \mathrm{NO}_{2}{ }^{-}-\mathrm{N}$, and $\mathrm{NO}_{3}{ }^{-}-\mathrm{N}$.

\subsection{Culture and Acclimation of $S$. intermedia and Periphyton}

Individuals of $S$. intermedia were placed in plastic containers (polypropylene; $0.500 \mathrm{~m}$ length $\times 0.155 \mathrm{~m}$ width $\times 0.140 \mathrm{~m}$ depth; $10.85 \mathrm{l}$ ) containing a 1:1 mixture of effluent and water collected upstream the effluent discharge in La Choza stream. In order to establish a typical biocenosis and to maintain the equilibrium in the system, the plants were acclimated in the mixture for 3 weeks prior to the experiment. The water was renewed weekly and its characterization is shown in Table 1. Within each container, acrylic plates were located for the development of indigenous periphyton (Pizarro and Alemanni 2005).

Both, acclimatization and assay, were conducted in a partially enclosed greenhouse within the nursery of native species at the natural protected area "Dique Ing. Roggero" (district of Moreno, Buenos Aires). The photoperiod corresponded to the month of December in Buenos Aires (14:10, light: dark).

\subsection{Lab-Scale Experiment with Continuous Recirculation of Wastewater}

Upon completion of the acclimation period, six continuous flow reactors were installed and filled with 8.81 of undiluted wastewater. In each reactor, a submersible pump was installed for continuous recirculation of wastewater at a rate of $0.60 \pm 0.05 \mathrm{ml} / \mathrm{s}$ in order to recreate the low speeds of current, characteristic of the streams in the Pampas (Feijoó and Lombardo 2007), and constructed wetlands for wastewater treatment (Ran et al. 2004).

Individuals of $S$. intermedia were distributed in three reactors selected randomly, covering approximately 50 $60 \%$ of the free surface (treatment Ar). The initial dry weight (DW) had a mean value of $1.04 \mathrm{~g}$ DW. Part of the liquid surface remained free of macrophytes using a screen, preventing the introduction of plants in the recirculation loop. The remaining three reactors without
Table 1 Characterization of the mixture used in the acclimation of $S$. intermedia and periphyton

\begin{tabular}{lll}
\hline Variable & Unit & Mean $\pm \mathrm{SD}$ \\
\hline $\mathrm{pH}$ & & $7.57 \pm 0.27$ \\
$\mathrm{EC}$ & $\mathrm{mS} / \mathrm{cm}$ & $1.15 \pm 0.04$ \\
$\mathrm{TSS}$ & $\mathrm{mg} / \mathrm{l}$ & $129 \pm 16$ \\
$\mathrm{NH}_{4}{ }^{+}-\mathrm{N}$ & $\mathrm{mg} / \mathrm{l}$ & $18.4 \pm 3.2$ \\
$\mathrm{NO}_{2}{ }^{-}-\mathrm{N}$ & $\mathrm{mg} / \mathrm{l}$ & $0.03 \pm 0.01$ \\
$\mathrm{NO}_{3}{ }^{-}-\mathrm{N}$ & $\mathrm{mg} / \mathrm{l}$ & $0.04 \pm 0.01$ \\
$\mathrm{DIN}^{-}$ & $\mathrm{mg} / \mathrm{l}$ & $18.5 \pm 3.2$ \\
$\mathrm{SRP}$ & $\mathrm{mg} / \mathrm{l}$ & $2.1 \pm 0.6$ \\
$\mathrm{TP}$ & $\mathrm{mg} / \mathrm{l}$ & $3.8 \pm 0.5$ \\
$\mathrm{TOC}$ & $\mathrm{mg} / \mathrm{l}$ & $93.2 \pm 11.7$ \\
$\mathrm{DOC}$ & $\mathrm{mg} / \mathrm{l}$ & $40.3 \pm 13.2$ \\
$\mathrm{POC}$ & $\mathrm{mg} / \mathrm{l}$ & $52.8 \pm 1.5$ \\
\hline
\end{tabular}


plants were left partially in darkness covering it with a plastic fabric to inhibit the growth of algae (control, treatment $\mathrm{Br}$ ). In all reactors were located randomly four acrylic plates with periphyton developed during the acclimatization period.

During the test, water temperature, $\mathrm{pH}, \mathrm{EC}$, and DO in each container were measured daily, according to the described methodology. In addition, water samples were taken at the beginning and end of the assay, carrying out immediately the corresponding physical and chemical determinations described in item 2.2. The test duration was 6 days. Upon study completion, the plant biomass was harvested and dried at $60^{\circ} \mathrm{C}$ in an oven to constant weight and then was determined dry weight (DW). The biomass growth was quantified by calculating the relative growth rate (RGR) (Huang et al. 2013).

Considering the effects of evaporation and evapotranspiration (Kyambadde et al. 2005), the removal percentage $(\mathrm{R} \%)$ of each analyte was calculated according to Eq. 1:

$\mathrm{R} \%=100 \times \frac{V_{i} \times C_{i}-V_{f} \times C_{f}}{V_{i} \times C_{i}}$

where $V_{\mathrm{i}}$ and $C_{\mathrm{i}}$ are the initial volume and concentration in each reactor and $V_{\mathrm{f}}$ and $C_{\mathrm{f}}$ the values at the end of the bioassay. The product $V \times C$ is the mass or load $(L)$ of each analyte in each reactor. The existence of statistically significant differences $(p<0.05)$ between the values of the final loads of the variables in both treatments was examined by Student's $t$ test. Non-normal variables and/ or heteroskedastic were previously transformed and, if not possible, nonparametric the Mann-Whitney $U$ test (Zar 1996) was used.

In addition, at the beginning and end of the test DW, ash weight (AW), ash-free dry weight (AFDW) and chlorophyll a (ChloA) were determined in periphyton, and then Lakatos and autotrophic indexes (AI) were calculated, according to the methodology set by Pizarro and Alemanni (2005). Lakatos indexes considered (a) the type of mass based on the dry weight (index Lm): high $\left(>4 \mathrm{mg} / \mathrm{cm}^{2}\right)$, medium $\left(2-4 \mathrm{mg} / \mathrm{cm}^{2}\right)$ and low $(<$ $2 \mathrm{mg} / \mathrm{cm}^{2}$ ); (b) according to the \% of ash (index La): I: inorganic (> $75 \%$ ), II: inorganic-organic (50-75\%), III: organic-inorganic (25-50\%), IV: organic $(<25 \%)$; (c) depending on the type of biomass according to the concentration of chlorophyll a (LChloA): I: autotrophic (> $0.60 \%$ ), II: auto-heterotrophic (0.25-0.60\%), III: hetero-autotrophic $(0.10-0.25 \%), \mathrm{IV}$ : heterotrophic $(<$
$0.10 \%$ ) (Lakatos 1989). The abundance of algae periphyton at class level (Chlorophyceae, Cyanophyceae, Bacillariophyceae and Euglenophyceae) was also estimated by the method of Utermöhl (1958), using an inverted microscope at $\times 400$ magnification. The samples were allowed to settle for at least $24 \mathrm{~h}$ in $5 \mathrm{ml}$ chambers. The algal density was calculated for each class. The data obtained were expressed in number of cells $/ \mathrm{cm}^{2}$. The number of counts in each chamber was carried out in a number of fields randomly selected, with an error $<15 \%$, according to Venrick (1978).

\section{Results and Discussion}

\subsection{Physical and Chemical Variables}

The initial $\mathrm{pH}$ was slightly alkaline in the two treatments. However, in reactors with plants (treatment Ar), lower $\mathrm{pH}$ values were determined along the test. In this treatment, the maximum average $\mathrm{pH}$ (8.26) was observed on the fourth day, whereas in treatment without plants (treatment $\mathrm{Br}$ ) the increasing trend remained constant throughout the study reaching a maximum mean value 8.55 on the sixth day (Fig. 1). The autotrophic and heterotrophic respiration produces $\mathrm{CO}_{2}$, resulting in the sustained drop in $\mathrm{pH}$ by carbon dioxide reaction with water to create carbonic acid (Reeder 2011) by the end of trial treatment with $S$. intermedia, according to the results found by Vermaat and Hanif (1998) in a trial with aquatic macrophytes growing in artificial wastewater. The nitrification process contributed to lowering the $\mathrm{pH}$ in the reactors with plants (Nimick et al. 2011). The mineralization of organic matter, respiration, and nitrification contributed with acidic species (Verma and Suthar 2014) that consumed part of bicarbonate alkalinity, which fell from an initial value of 847 to $735 \mathrm{mg} / \mathrm{l}$ in the treatment Ar, with an increase of the final average concentration in treatment $\mathrm{Br}(909 \mathrm{mg} / \mathrm{l})$ associated with evaporation.

The EC values fell within $24 \mathrm{~h}$ in both treatments and then increased in the third and fifth day in $\mathrm{Ar}$ and $\mathrm{Br}$ treatments, respectively. The later decrease of electrical conductivity was more noticeable in the Ar treatment (Fig. 1) by the presence of macrophytes, which can remove part of dissolved ions (Yang et al. 2015).

The amount of dissolved oxygen in strong effluents is usually negligible (Sun et al. 2005). During the initial phase of the test, DO concentration remained virtually 
Fig. 1 Values of $\mathrm{pH}, \mathrm{EC}$, and DO in wastewater, in the treatment with $S$. intermedia (treatment Ar) and without plants, in darkness (treatment $\mathrm{Br}$ )

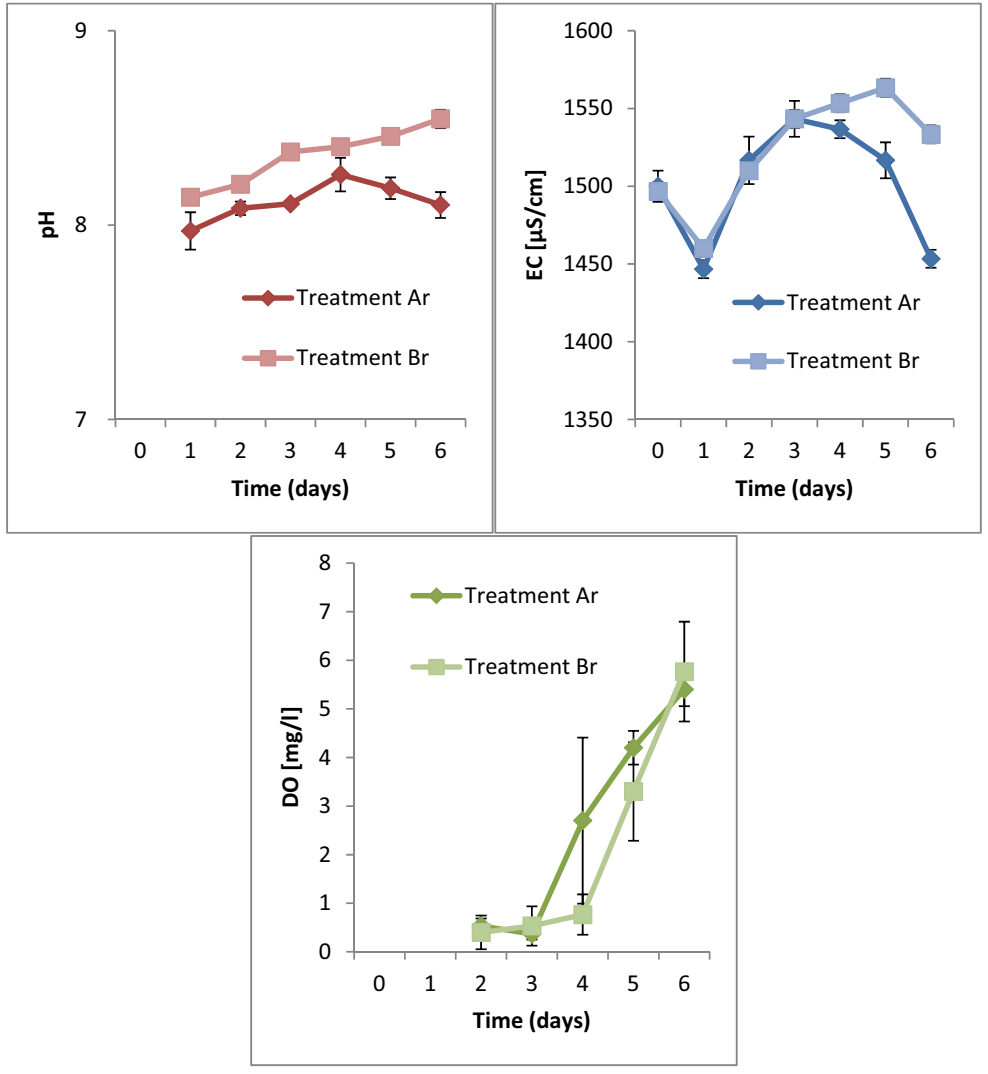

constant, with values below $1 \mathrm{mg} / \mathrm{l}$ until the third day in both treatments. Then higher mean increases in DO concentrations were observed in the case of treatment Ar (Fig. 1). No significant differences in the mean concentrations were observed for both treatments; therefore, the oxygenation of the wastewater responded primarily to the diffusion of oxygen from the air, increased by recirculation of the liquid and not the positive balance of photosynthesis-respiration in illuminated reactors. Regarding the consumption of oxygen, theoretically $1 \mathrm{~g} \mathrm{O}_{2}$ is required to remove $1 \mathrm{~g} \mathrm{BOD5}$, and up to $4.35 \mathrm{~g} \mathrm{O}_{2}$ to transform $1 \mathrm{~g}$ ammoniacal nitrogen into nitrate (Sun et al. 2005). Then, oxygen supply from air diffusion exceeds the consumption by decomposition and nitrification.

The average TSS concentration at baseline was $125 \mathrm{mg} / \mathrm{l}$, while the final concentration in the treatment Ar was significantly lower $(45 \mathrm{mg} / \mathrm{l})$ than in the absence of plants $(72 \mathrm{mg} / \mathrm{l})$. Considering the mass of total suspended solids per reactor, the removals were 69.7 $\pm 3.9 \%$ and $49.9 \pm 4.2 \%$ for treatments $\mathrm{Ar}$ and $\mathrm{Br}$, respectively (Table 2), although on a larger scale, removal could be lower (Badalians Gholikandi et al.
2009). It should be noted that the solid settling took place in both treatments despite water circulation. Furthermore, the retention of suspended particulate matter in different plant organs could explain the higher TSS removal in the presence of plants.

The effects of evaporation and evapotranspiration should be considered in large scale applications of wastewater phytoremediation, since the wetlands and lagoons used are often shallow (Körner et al. 2003), and therefore, the surface/volume ratio is high. Therefore, the analysis of the effectiveness of treatment should be performed considering not only the concentrations (Fig. 2) but also the mass or load (Table 2) of solids and nutrients (Soda et al. 2013). There were statistically significant differences $(p=0.013)$ between macrophyte evapotranspiration (16.0 $\pm 1.2 \%)$ and evaporation in the reactors without plants $(13.0 \pm 0.3 \%)$. Load analysis reveals that there was an effective removal of TSS, $\mathrm{NH}_{4}{ }^{+}-\mathrm{N}, \mathrm{DIN}, \mathrm{TP}, \mathrm{TOC}, \mathrm{DOC}$ and POC in both treatments (Table 2). Conversely, increases were observed in $\mathrm{NO}_{2}{ }^{-}-\mathrm{N}$ (treatment $\mathrm{Ar}$ ), $\mathrm{NO}_{3}{ }^{-}-\mathrm{N}$ (both treatments) and SRP (treatment Br). Statistical analysis revealed significant differences between the final loads of 
Table 2 Initial and final values of the loads $(L)$ of TSS and nutrients in water in treatments $\mathrm{Ar}$ (with $S$. intermedia individuals) and Br (without plants), detailing the $p$ values and removal percentages $(\mathrm{R} \%)$

\begin{tabular}{|c|c|c|c|c|c|}
\hline Variable & Treatment & $\begin{array}{l}\text { Initial L } \\
\text { (mg/reactor) }\end{array}$ & $\begin{array}{l}\text { Final L } \\
\text { (mg/reactor) }\end{array}$ & $p$ value & $\mathrm{R} \%$ \\
\hline \multirow[t]{2}{*}{ TSS } & $\mathrm{Ar}$ & 1096 & $332 \pm 43$ & $0.004 * *$ & $69.7 \pm 3.9$ \\
\hline & $\mathrm{Br}$ & & $549 \pm 45$ & & $49.9 \pm 4.2$ \\
\hline \multirow[t]{2}{*}{$\mathrm{NH}_{4}^{+}-\mathrm{N}$} & $\mathrm{Ar}$ & 295.38 & $47.22 \pm 10.13$ & $0.000 * *$ & $84.0 \pm 3.4$ \\
\hline & $\mathrm{Br}$ & & $199.76 \pm 4.92$ & & $32.4 \pm 1.7$ \\
\hline \multirow[t]{2}{*}{$\mathrm{NO}_{2}{ }^{-}-\mathrm{N} \dagger$} & $\mathrm{Ar}$ & 0.40 & $74.85 \pm 15.81$ & $0.015^{*}$ & + \\
\hline & $\mathrm{Br}$ & & $0.20 \pm 0.13$ & & $50.3 \pm 33.7$ \\
\hline \multirow[t]{2}{*}{$\mathrm{NO}_{3}{ }^{-}-\mathrm{N}$} & $\mathrm{Ar}$ & 0.13 & $58.02 \pm 11.24$ & $0.001 * *$ & + \\
\hline & $\mathrm{Br}$ & & $0.91 \pm 0.91$ & & + \\
\hline \multirow[t]{2}{*}{ DIN } & $\mathrm{Ar}$ & 295.94 & $180.09 \pm 17.56$ & 0.124 & $39.1 \pm 5.9$ \\
\hline & $\mathrm{Br}$ & & $200.87 \pm 5.93$ & & $32.1 \pm 2.0$ \\
\hline \multirow[t]{2}{*}{ SRP } & $\mathrm{Ar}$ & 35.14 & $32.38 \pm 1.63$ & $0.013^{*}$ & $7.9 \pm 4.6$ \\
\hline & $\mathrm{Br}$ & & $40.68 \pm 2.91$ & & + \\
\hline \multirow[t]{2}{*}{ TP } & $\mathrm{Ar}$ & 54.07 & $33.45 \pm 0.97$ & $0.000 * *$ & $38.1 \pm 1.8$ \\
\hline & $\mathrm{Br}$ & & $44.43 \pm 0.39$ & & $17.8 \pm 0.7$ \\
\hline \multirow[t]{2}{*}{ TOC } & $\mathrm{Ar}$ & 894.1 & $301.3 \pm 26.7$ & 0.770 & $66.3 \pm 3.0$ \\
\hline & $\mathrm{Br}$ & & $310.2 \pm 40.8$ & & $65.3 \pm 4.6$ \\
\hline \multirow[t]{2}{*}{ DOC } & $\mathrm{Ar}$ & 391.4 & $143.2 \pm 7.5$ & 0.417 & $63.4 \pm 1.9$ \\
\hline & $\mathrm{Br}$ & & $150.6 \pm 12.0$ & & $61.5 \pm 3.1$ \\
\hline \multirow[t]{2}{*}{ POC } & $\mathrm{Ar}$ & 502.7 & $158.1 \pm 24.7$ & 0.513 & $68.5 \pm 4.9$ \\
\hline & $\mathrm{Br}$ & & $159.6 \pm 50.0$ & & $68.3 \pm 10.0$ \\
\hline
\end{tabular}

The asterisk indicates statistically significant difference $(p<0.05)$ or highly significant (double asterisks $)(p<0.01)$ between both treatments final loads according to the Student $t$ test. The plus sign indicates an increase of the load from baseline. The dagger indicates no equal variances were assumed for calculating the $p$ value. The double daggers indicates the variable was not normalizable; the $p$ value corresponds to the Mann-Whitney $U$ test

TSS, $\mathrm{NH}_{4}{ }^{+}-\mathrm{N}, \mathrm{NO}_{2}{ }^{-}-\mathrm{N}, \mathrm{NO}_{3}{ }^{-}-\mathrm{N}, \mathrm{SRP}$, and $\mathrm{TP}$ of both treatments (Table 2).

The main nitrogen form at baseline was ammonium, with very low levels of nitrites and nitrates (Fig. 2). This nitrogen imbalance was higher in Ar treatment (Table 2). The biofilm developed onto the roots causing ammonium assimilation and removal from wastewater. Bacterial nitrification process was mainly observed in treatment $\mathrm{Ar}$, with ammonium removal of $84.0 \pm 3.4 \%$ (Table 2) and significant increases in nitrite and nitrate concentrations (Fig. 2) and loads (Table 2) over initials. Nitrification occurred mainly at the second half of the trial, favored by the presence of $S$. intermedia (Basílico et al. 2013). Removal of ammonium nitrogen and lower $\mathrm{pH}$ resulted in lower ammonia concentrations and hence ammonia volatilization. Then, the risk of toxicity to aquatic biota associated with high concentrations of un-ionized ammonia at high pH (Körner et al. 2003) decreased. The removal of ammonium-N was higher than the value of $47.9 \%$ in an experiment with water recirculation (Sun et al. 2005). The subsequent change in the source of $\mathrm{N}$ from ammonium to nitrate contributed to a low removal of DIN in treatment with plants $(\mathrm{Xu}$ and Shen 2011). Therefore, to increase the removal of DIN in the presence of $S$. intermedia, it should be coupled to a subsequent system for effluent denitrification (Ye and $\mathrm{Li}$ 2009) through an anaerobic reactor or increasing the retention time to result in nitrate removal by algae and macrophytes. Another alternative is to optimize the process for simultaneous nitrification/ denitrification (SND) of the effluent (Zhang et al. 2008). In treatment without plants $(\mathrm{Br})$, ammonia volatilization favored by high $\mathrm{pH}$, might be the main factor contributing to the removal of DIN.

Mean concentrations of TP decreased in both treatments during the assay, showing a greater removal in $S$. intermedia treatment regarding control treatment $(\mathrm{Br})$, reaching $38.1 \pm 1.8 \%$ (Table 2 ). The concentration and 
Fig. 2 Initial and final concentrations of $\mathrm{NH}_{4}{ }^{+}-\mathrm{N}, \mathrm{DIN}$, $\mathrm{NO}_{2}{ }^{-}-\mathrm{N}$, and $\mathrm{NO}_{3}{ }^{-}-\mathrm{N}$ (above) and SRP, TP, TOC, DOC, and POC (below) in wastewater treatment with $S$. intermedia (treatment Ar) and without plants in darkness (treatment $\mathrm{Br}$ )

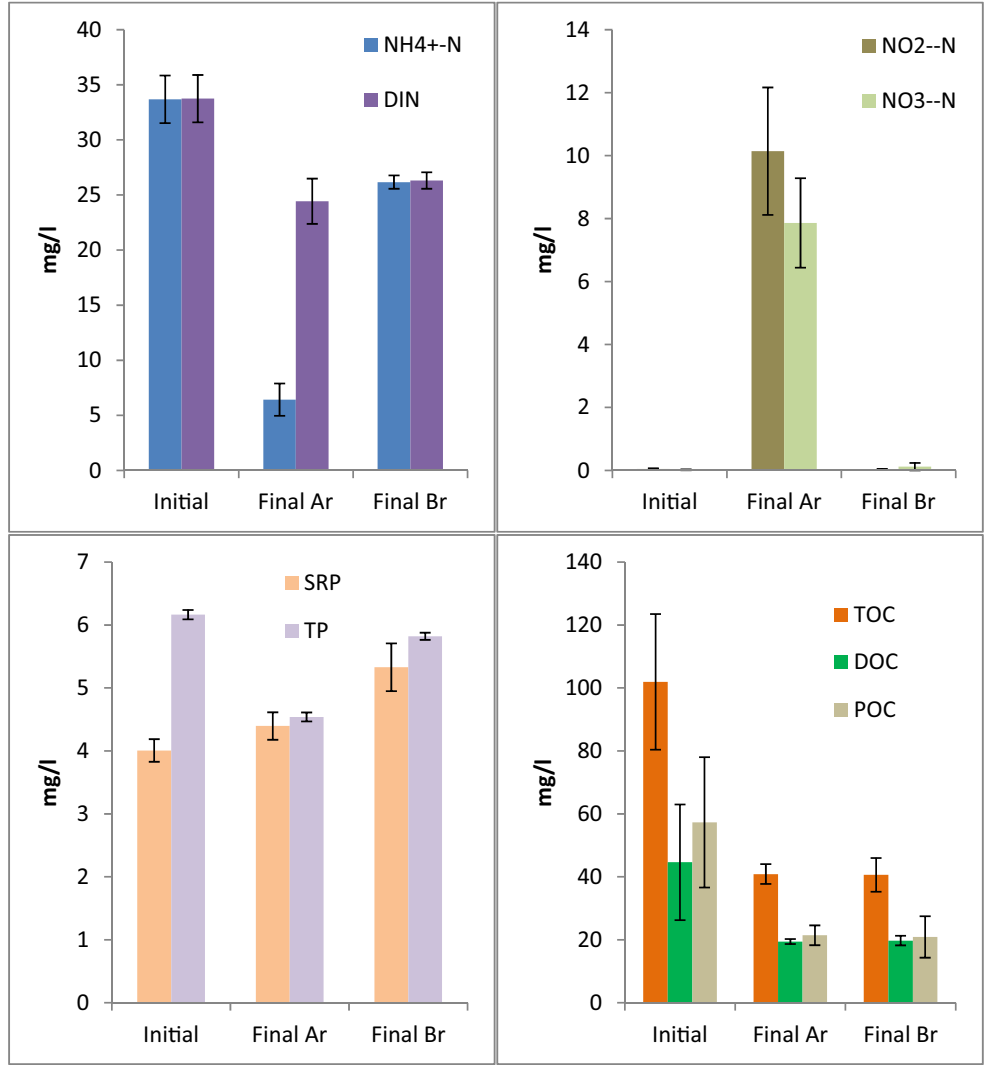

average loads of TP were lower in the treatment with plants due to the retention of particulate matter by biofiltration and by macrophytes assimilation (Shilton et al. 2012). The initial concentration of SRP was $4.0 \mathrm{mg} / 1$ and the mean final concentrations exceeded the initial in both treatments (Ar: $4.4 \mathrm{mg} / \mathrm{l} ; \mathrm{Br}: 5.3 \mathrm{mg} / \mathrm{l}$ ), although the difference was greater in $\mathrm{Br}$ (Fig. 2). In terms of SRP load, there was only a low removal treatment in $\operatorname{Ar}(7.9 \pm 4.6 \%)$ and was observed an increase in treatment $\mathrm{Br}$ (Table 2). One part of the $\mathrm{P}$ assimilated by algae and macrophytes subsequently returned to the water column as a result of decomposition and desorption (Kadlec 2006) and resulted in slight increase of SRP concentration in Ar treatment by the end of the trial (Fig. 2). Absence of macrophytes resulted in higher final SRP concentration in the treatment $\mathrm{Br}$. Changes in redox conditions could favor the adsorption or release of phosphate (Reed et al. 2006). In the bioassay anoxic conditions were maintained in both treatments during the first period, favoring the release of dissolved $\mathrm{P}$ from the particulate material. Then, in treatment with plants (Ar), higher DO levels achieved inhibited such release. Patel and Kanungo (2010) also argue that the assimilation of phosphorus is short term as it quickly is released back into the water column.

Removal of organic particulate material is of great importance in the treatment of wastewater and many toxics are usually found attached to the organic fraction of the sediment (Rulkens 2005). TOC levels, both in terms of loads (Table 2) and concentrations (Fig. 2), decreased markedly in both treatments $(\approx 65-66 \%$; Table 2), due to the sedimentation of particulate matter (POC). Also, DOC levels also decreased in both treatments regarding initial levels, which could be related to the consumption by heterotrophic microorganisms in the reactors. High levels of dissolved and particulate organic matter in the effluent favor the development of heterotrophic microorganisms, anaerobic biota in the initial phase, and then aerobic biota. The fraction of particulate organic carbon (POC) was higher than the dissolved (DOC) at the start and end of the trial, approximately the same final concentrations of both fractions were observed in both treatments (Fig. 2). However, considering the evaporation, the values of DOC removal was $63.4 \pm 1.9 \%$ and $61.5 \pm 3.1 \%$ for treatments Ar and $\mathrm{Br}$, respectively, with similar values $(\approx 68 \%)$ in the case 
of POC (Table 2). Körner et al. (1998) found that Lemna gibba had no significant role in the removal of DOC from a treatment plant effluent, although in terms of COD removal of organic matter was more rapid in the presence of the species. The organic matter was degraded through bacterial oxidation consuming the DO provided by algae and macrophytes and simultaneously providing $\mathrm{CO}_{2}$ and nutrients for algae biosynthesis (Liang et al. 1998).

\subsection{Biomass of $S$. intermedia}

The mean dry biomass of $S$. intermedia at the end of assay was 2.2 times higher than the initial biomass, resulting in a relative growth rate (RGR) of $0.130 \mathrm{~g} /$ $\mathrm{g}$ day and a productivity of $16.4 \mathrm{t} \mathrm{DW/ha} \mathrm{year,} \mathrm{a} \mathrm{higher}$ value than $11.3 \mathrm{t} \mathrm{DW} / \mathrm{ha}$ year reported by Reddy and DeBusk (1985) for Spirodela polyrhiza under nonlimiting nutrient. Besides nutrient concentrations, temperature, and photoperiod and light intensity (Yin et al. 2015), there are other factors that can modify the macrophyte biomass production, such as the frequency of harvest and the presence of other macrophytes species. Throughout the test, water average temperature was high $\left(24{ }^{\circ} \mathrm{C}\right)$ because the trial was carried out in late spring, which is an important factor in biomass production and nutrient removal from wastewater since with a temperature of $27^{\circ} \mathrm{C}$ the area colonized by duckweed can be doubled every 4 days (Curt Fernández de la Mora 2005). The biweekly harvesting increased the productivity of Spirodela oligorrhyza grown in a pig farm effluent (Xu and Shen 2011). The multispecies culture of duckweed (Zhao et al. 2014) and other macrophytes (Eichhornia + Lemna + Spirodela, Ansari et al. 2015) not only can increase the total biomass but also the removal of $\mathrm{N}$ and $\mathrm{P}$.

\subsection{Periphyton Characterization}

According to the values of chlorophyll a, dry weight (DW), ash weight (AW) and ash-free dry weight (AFDW), the mass of periphyton increased throughout the trial in both treatments, although in the treatment $\mathrm{Br}$ the reactors were shaded. The average initial concentration of chlorophyll a was $0.3 \mu \mathrm{g} / \mathrm{cm}^{2}$, and at the end of the test, values doubled in treatment $\operatorname{Br}\left(0.6 \mu \mathrm{g} / \mathrm{cm}^{2}\right)$ and reached $1.3 \mu \mathrm{g} / \mathrm{cm}^{2}$ in treatment Ar.

The DW increased from an initial value of $0.039 \mathrm{mg} /$ $\mathrm{cm}^{2}$ to values of 0.145 and $0.101 \mathrm{mg} / \mathrm{cm}^{2}$ for treatments Ar and Br, respectively (Table 3). The AFDW, which represents the organic fraction of periphyton, increased in both treatments, being $0.074 \mathrm{mg} / \mathrm{cm}^{2}$ in $\mathrm{Br}$ and reaching an average value of $0.106 \mathrm{mg} / \mathrm{cm}^{2}$ in Ar. The AFDW/DW ratio decreased from an initial value of 0.79 to a value of 0.73 for both treatments, indicating the deposition of inorganic particulate material on the periphyton.

The Lakatos indexes (Lm, LChloA, and La) and autotrophic index (AI) allowed typify the periphytic community developed on artificial substrate at baseline and after 6 days of the bioassay in both treatments. It was observed that the mass was low and periphyton was autotrophic in all cases, varying from organic to organicinorganic along the test in both treatments (Table 3), indicating the contribution of particulate inorganic material periphyton, the product of the mineralization processes operating in the system throughout the trial. The AI values greater than 100 indicate a higher proportion of heterotrophic organisms (mainly bacteria) in the treatment without plants and darkness at the beginning and the end of the test, revealing a typical periphytic community of environments enriched by organic matter (treatment Br) (Table 3). In contrast, in the treatment with plants, AI decreased after the trial, which indicates

Table 3 Classification of the periphytic community developed on acrylic sheets during the bioassay by Lakatos indexes (Lakatos 1989) (Lm, LCloA, and La) and autorophic index (AI) (APHA, AWWA and WPCF 1992). Au autotrophic, Or organic, O-I organic-inorganic

\begin{tabular}{|c|c|c|c|c|c|c|c|}
\hline \multirow[t]{3}{*}{ Treatment } & \multicolumn{7}{|l|}{ Indexes } \\
\hline & \multicolumn{2}{|l|}{$\mathrm{Lm}$} & \multicolumn{2}{|l|}{ LChloA } & \multicolumn{2}{|l|}{$\mathrm{La}$} & \multirow[t]{2}{*}{ AI } \\
\hline & Value $\left(\mathrm{mgDW} / \mathrm{cm}^{2}\right)$ & Type & Value (\%) & Type & Value $(\%)$ & Type & \\
\hline Initial & $0.04 \pm 0.01$ & Low & $1.0 \pm 0.2$ & $\mathrm{I}(\mathrm{Au})$ & $20 \pm 7$ & IV (Or) & $107 \pm 27$ \\
\hline Final Ar & $0.14 \pm 0.01$ & Low & $1.3 \pm 0.3$ & $\mathrm{I}(\mathrm{Au})$ & $27 \pm 4$ & III (O-I) & $82 \pm 19$ \\
\hline Final Br & $0.10 \pm 0.02$ & Low & $0.9 \pm 0.1$ & $\mathrm{I}(\mathrm{Au})$ & $26 \pm 5$ & III (O-I) & $116 \pm 7$ \\
\hline
\end{tabular}


Fig. 3 Abundance of the main groups of algae periphyton, in the presence of individuals of

S. intermedia (treatment Ar) and in the absence of the species with partial shading (treatment $\mathrm{Br}$ )

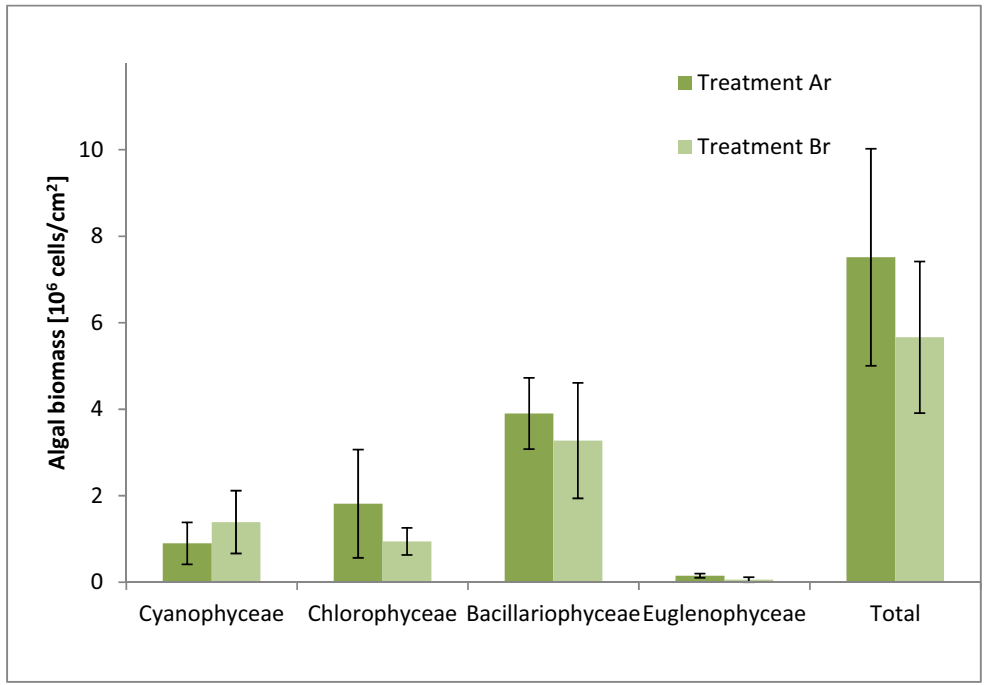

a decline of heterotrophic organisms and/or organic detritus and increased autotrophic organisms that were favored by the increased illumination and the presence of floating plants. The greater abundance of periphyton algae (Fig. 3) and the lowest values of AI in treatment Ar (Table 3) indicate a more advanced depuration state, since the organic component of detritus dropped.

In relation to the composition of periphyton algae classes, no statistically significant differences between treatments $\mathrm{Ar}$ and $\mathrm{Br}$ were observed. Also, the total numbers of individuals, expressed as number of cells $/ \mathrm{cm}^{2}$ due to the presence of filamentous species, did not change significantly. This could be because the same floating plants present in the Ar treatment prevented the entry of light into plastic containers, producing the same effect of shade in the treatment $\mathrm{Br}$. The dominance of diatoms (Bacillariophyceae) after the trial (Fig. 3) reveals a better water quality in both treatments that relates to increasing tenors DO and the reduction of dissolved nutrients and organic matter (Hoagland et al. 1982). On the other hand, the low representation of Euglenophyceae class after the trial (Fig. 3) is also indicative of improved water quality. The euglenophytes are considered a pioneer group consisting of opportunistic species tolerant to high organic loads typical wastewater and general stress conditions (Chindah et al. 2009). These trends were stronger in the Ar treatment, where the presence of floating vegetation and autotrophic organisms in the periphyton favored the debugging process.

\section{Conclusions}

Oxygenation of the wastewater was not associated to a biological factor but to $\mathrm{O}_{2}$ diffusion increased by the recirculation of the effluent. The effect of evapotranspiration was significant and should be considered in the treatment of effluents in larger scale applications, and analysis should be performed on both concentrations and loads of nutrients, organic matter, and other pollutants. The presence of duckweed $S$. intermedia and periphyton community contributed significantly to the removal of TSS, ammonium nitrogen, and phosphorus from poultry wastewater and also favored the nitrification process. The decrease in $\mathrm{pH}$ and the high ammonium nitrogen removal by nitrification helped to reduce the risk of toxicity to aquatic biota associated with high concentrations of ammonium and ammonia. Since the removal of DIN was relatively low, it is necessary either to extend the residence time or add further treatment to promote biomass growth and consequently the assimilation of $\mathrm{N}$, with the additional advantage of increasing the removal of $\mathrm{P}$. The dominance of Bacillariophyceae on other groups of periphyton algae and the low representation of Euglenophyceae class indicated an advanced stage of the treatment process at the end of the bioassay.

Acknowledgments The authors wish to thank the Natural Protected Area "Dique Ing. Roggero" (Moreno, Buenos Aires), particularly to Ignacio Healion and Roberto Ferrer. Marina González collaborated with the revision of the manuscript in English. The research was funded by National Scientific and Technical Research Council (CONICET, PIP 0323). 


\section{References}

Ansari, A. A., Trivedi, S., Khan, F. A., Gill, S. S., Perveen, R., Dar, M. I., et al. (2015). Phytoremediation of eutrophic waters. In A. A. Ansari et al. (Eds.), Phytoremediation: management of environmental contaminants (Vol. 2, pp. 41-50). Cham: Springer.

APHA, AWWA \& WPCF. (1992). Métodos normalizados para el análisis de aguas potables y residuales (17th ed.). Madrid: Editorial Díaz de Santos.

Avilés, C., Loza-Tavera, H., Terry, N., \& Moreno-Sánchez, R. (2003). Mercury pretreatment selects an enhanced cadmium-accumulating phenotype in Euglena gracilis. Archives of Microbiology, 180, 1-10.

Badalians Gholikandi, G., Moradhasseli, M., \& Riahi, R. (2009). Treatment of domestic wastewater in a pilot-scale HSFCW in West Iran. Desalination, 248(1-3), 977-987.

Basílico, G., de Cabo, L., \& Faggi, A. (2013). Impacts of composite wastewater on a Pampean stream (Argentina) and phytoremediation alternative with Spirodela intermedia Koch (Lemnaceae) growing in batch reactors. Journal of Environmental Management, 115, 53-59.

Basílico, G., de Cabo, L., \& Faggi, A. (2015). Phytoremediation of water and wastewater: on-site and full-scale applications. In A. A. Ansari et al. (Eds.), Phytoremediation: management of environmental contaminants (Vol. 2, pp. 51-60). Cham: Springer.

Benning, R. (2014). El costo oculto de la carne y las salchichas. In M. A. Kalverkamp \& G. Ledger (Eds.), Atlas de la carne (pp. 26-27). Santiago de Chile: Fundación Heinrich Böll Stiftung.

Boelee, N. C., Temmink, H., Janssen, M., Buisman, C. J. N., \& Wijffels, R. H. (2011). Nitrogen and phosphorus removal from municipal wastewater effluent using microalgal biofilms. Water Research, 45, 5925-5933.

Chindah, A. C., Braide, S. A., Amakiri, J., \& Kiolawson Ajibulu, O. O. (2009). Periphyton succession in a waste water treatment pond. Revista UDO Agrícola, 9(3), 681-699.

Curt Fernández de la Mora, M. D. (2005). Macrófitas de interés en fitodepuración. In Fernández González, J. (Ed.). Manual de Fitorredepuración. Fundación Global Nature. http://www. fundacionglobalnature.org/macrophytes/Manual $\% 20$ sobre $\%$ 20fitodepuracion.htm. Accessed November 2015.

Feijoó, C. S., \& Lombardo, R. J. (2007). Baseline water quality and macrophyte assemblages in Pampean streams: a regional approach. Water Research, 41, 1399-1410.

Feijoó, C., Giorgi, A., \& Ferreiro, N. (2011). Phosphate uptake in a macrophyte-rich Pampean stream. Limnologica, 41, 285289.

Finnegan, C. J., van Egmond, R. A., Price, O. R., \& Whelan, M. J. (2009). Continuous-flow laboratory simulation of stream water quality changes downstream of an untreated wastewater discharge. Water Research, 42, 1993-2001.

Ge, S., Wang, S., Yang, X., Qiu, S., Li, B., \& Peng, Y. (2015). Detection of nitrifiers and evaluation of partial nitrification for wastewater treatment: a review. Chemosphere, 140, 8598.

Gekeler, W., Grill, E., Winnacker, E. L., \& Zenk, M. H. (1988). Algae sequester heavy metals via synthesis of phytochelatin complexes. Archives of Microbiology, 150, 197-202.
Golterman, H., Clymo, R., \& Ohndtad, M. (1978). Methods for the physical and chemical examination of freshwaters (2nd ed.). Oxford: Blackwell Scientific.

Heuillet, E., Moreau, A., Halpren, S., Jeanne, N., \& Puiseux-Dao, S. (1986). Cadmium binding to a thiol molecule in vacuoles of Dunaliella bioculata contaminated with $\mathrm{CdCl}_{2}$ : electron probe microanalysis. Biology of the Cell, 58, 79-86.

Hoagland, K. D., Roemer, S. C., \& Rosowski, J. R. (1982). Colonization and community structure of two periphyton assemblages, with emphasis on the diatoms (Bacillariophyceae). American Journal of Botany, 69, 188213.

Huang, L., Lu, Y., Gao, X., Du, G., Ma, X., Liu, M., et al. (2013). Ammonium-induced oxidative stress on plant growth and antioxidative response of duckweed (Lemna minor L.). Ecological Engineering, 58, 355-362.

Kadlec, R. H. (2006). Free surface wetlands for phosphorus removal: the position of the Everglades Nutrient Removal Project. Ecological Engineering, 27(4), 361-379.

Körner, S., Lyatuu, G. B., \& Vermaat, J. E. (1998). The influence of Lemna gibba L. on the degradation of organic material in duckweed-covered domestic wastewater. Water Research, 32(10), 3092-3098.

Körner, S., Vermaat, J. E., \& Veenstra, S. (2003). The capacity of duckweed to treat wastewater: ecological considerations for a sound design. Journal of Environmental Quality, 32(5), $1583-1590$

Kyambadde, J., Kansiime, F., \& Dalhammar, G. (2005). Nitrogen and phosphorus removal in substrate-free pilot constructed wetlands with horizontal surface flow in Uganda. Water, Air, and Soil Pollution, 165, 37-59.

Lakatos, G. (1989). Composition of reed periphyton (biotecton) in the Hungarian part of lake Fertö. Biologisches Forschungsinstitut für Burgenland, 71, 125-134.

Levi, P. S., Riis, T., Alnøe, A. B., Pipoch, M., Maetzke, K., Bruus, C., et al. (2015). Macrophyte complexity controls nutrient uptake in lowland streams. Ecosystems, 18, 914-931.

Lewis, M. A., \& Wang, W. (1997). Water quality and aquatic plants. In W. Wang et al. (Eds.), Plants for environmental studies (pp. 141-175). Boca Raton: CRC Press LLC.

Liang, Y., Cheung, R. Y. H., Everitt, S., \& Wong, M. H. (1998). Reclamation of wastewater for polyculture of freshwater fish: wastewater treatment in ponds. Water Research, 32(6), 1864 1880.

Mackereth, F., Heron, J., \& Talling, J. (1989). Water analysis: some revised methods for limnologists (2nd ed.). Cumbria: Freshwater Biological Association. Scientific publication No. 36.

Mazzeo, N. (1993). Revisión de la familia Lemnaceae en Chile. Gayana Botánica, 50, 29-40.

Mendoza-Cózatl, D. G., \& Moreno-Sánchez, R. (2005). Cd ${ }^{2+}$ transport and storage in the chloroplast of Euglena gracilis. Biochimica et Biophysica Acta, 1706, 88-97.

Mohan, B. S., \& Hosetti, B. B. (1999). Aquatic plants for toxicity assessment. Environmental Research, 81, 259-274.

Nicol, C. J., \& Davies, A. (2013). Bienestar de las aves de corral en los países en desarrollo. In Revisión del desarrollo agrícola. Organización de las Naciones Unidas para la Alimentación y la Agricultura (FAO). http://www.fao.org/docrep/019/ i3531s/i3531s.pdf. Accessed September 2015. 
Nimick, D. A., Gammons, C. H., \& Parker, S. R. (2011). Diel biogeochemical processes and their effect on the aqueous chemistry of streams: a review. Chemical Geology, 283(1-2), 3-17.

Patel, D. K., \& Kanungo, V. K. (2010). Phytoremediation potential of duckweed (Lemna minor L: a tiny aquatic plant) in the removal of pollutants from domestic wastewater with special reference to nutrients. The Bioscan, 5(3), 355-358.

Pizarro, H., \& Alemanni, M. E. (2005). Variables físico-químicas del agua y su influencia en la biomasa del perifiton en un tramo inferior del Río Luján (Provincia de Buenos Aires). Ecología Austral, 15, 73-88.

Ran, N., Agami, M., \& Oron, G. (2004). A pilot study of constructed wetlands using duckweed (Lemna gibba L.) for treatment of domestic primary effluent in Israel. Water Research, 38(9), 2241-2248.

Reddy, K. R., \& DeBusk, W. F. (1985). Growth characteristics of aquatic macrophytes cultured in nutrient-enriched water: II. Azolla, Duckweed and Salvinia. Economic Botany, 39(2), 200-208.

Reed, S. C., Crites, R. W., \& Middlebrooks, E. J. (2006). Natural wastewater treatment systems. Boca Ratón: Taylor and Francis Group.

Reeder, B. C. (2011). Assessing constructed wetland functional success using diel changes in dissolved oxygen, $\mathrm{pH}$, and temperature in submerged, emergent, and open-water habitats in the Beaver Creek Wetlands Complex, Kentucky (USA). Ecological Engineering, 37(11), 1772-1778.

Rulkens, W. (2005). Introduction to the treatment of polluted sediments. Reviews in Environmental Science and Bio/ Technology, 4, 213-221.

Salminen, E., Rintala, J., Härkönen, J., Kuitunen, M., Högmander, H., \& Oikari, A. (2001). Anaerobically digested poultry slaughterhouse wastes as fertiliser in agriculture. Bioresource Technology, 78(1), 81-88.

Sharma, S. (2014). La gallina infeliz - El imparable boom avícola en el Mundo. In M. A. Kalverkamp \& G. Ledger (Eds.), Atlas de la carne (pp. 46-47). Fundación Heinrich Böll Stiftung: Santiago de Chile.

Shilton, A. N., Powell, N., \& Guieysse, B. (2012). Plant based phosphorus recovery from wastewater via algae and macrophytes. Current Opinion in Biotechnology, 23(6), 884-889.

Soda, S., Kawahata, Y., Takai, Y., Mishima, D., Fujita, M., \& Ike, M. (2013). Kinetics of nutrient removal and biomass production by duckweed Wolffia arrhiza in continuous-flow mesocosms. Ecological Engineering, 57, 210-215.

Srivastava, J., Gupta, A., \& Chandra, H. (2008). Managing water quality with aquatic macrophytes. Reviews in Environmental Science and Biotechnology, 7, 255-256.

Strickland, J., \& Parsons, T. (1972). A practical handbook of seawater analysis (2nd ed.). Ottawa: Fisheries Research Board of Canada. Bulletin No. 167.

Sun, G., Zhao, Y., \& Allen, S. (2005). Enhanced removal of organic matter and ammoniacal-nitrogen in a column experiment of tidal flow constructed wetland system. Journal of Biotechnology, 115(2), 189-197.

Utermöhl, H. (1958). Zur vervollkommnung der quantitativen phytoplankton methodik. Mitteilungen der Internationale Limnologische Vereingung, 9, 1-38.

Venrick, E. L. (1978). How many cells to count? In Phytoplankton Manual, Monographs on oceanographic methodology (pp. 167-180). Paris: A. Sournia, UNESCO Press.

Verma, R., \& Suthar, S. (2014). Synchronized urban wastewater treatment and biomass production using duckweed Lemna gibba L. Ecological Engineering, 64, 337-343.

Vermaat, J. E., \& Hanif, M. K. (1998). Performance of common duckweed species (Lemnaceae) and the waterfern Azolla filiculoides on different types of waste water. Water Research, 32, 2569-2576.

Vilches, C., \& Giorgi, A. (2010). Metabolism in a macrophyte-rich stream exposed to flooding. Hydrobiologia, 654(1), 57-65.

Wilkie, A. C., \& Mulbry, W. W. (2002). Recovery of dairy manure nutrients by benthic freshwater algae. Bioresource Technology, 84(1), 81-91.

Wu, Y., Xia, L., Yu, Z., Shabbir, S., \& Kerr, P. G. (2014). In situ bioremediation of surface waters by periphytons. Bioresource Technology, 151, 367-372.

$\mathrm{Xu}$, J., \& Shen, G. (2011). Growing duckweed in swine wastewater for nutrient recovery and biomass production. Bioresource Technology, 102, 848-853.

Yang, Y. N., Sheng, Q., Zhang, L., Kang, H. Q., \& Liu, Y. (2015). Desalination of saline farmland drainage water through wetland plants. Agricultural Water Management, 156, 19-29.

Ye, F., \& Li, Y. (2009). Enhancement of nitrogen removal in towery hybrid constructed wetland to treat domestic wastewater for small rural communities. Ecological Engineering, 35, 1043-1050.

Yetilmezsoy, K., \& Sapci-Zengin, Z. (2009). Recovery of ammonium nitrogen from the effluent of UASB treating poultry manure wastewater by MAP precipitation as a slow release fertilizer. Journal of Hazardous Materials, 166(1), 260-269.

Yin, Y., Yu, C., Yu, L., Zhao, J., Sun, C., Ma, Y., et al. (2015). The influence of light intensity and photoperiod on duckweed biomass and starch accumulation for bioethanol production. Bioresource Technology, 187, 84-90.

Zar, J. H. (1996). Bioestatistical analysis. New Jersey: Prentice Hall.

Zhang, L., Wei, C., Zhang, K., Zhang, C., Fang, Q., \& Li, S. (2008). Effects of temperature on simultaneous nitrification and denitrification via nitrite in a sequencing batch biofilm reactor. Bioprocess and Biosystems Engineering, 32(2), 175182.

Zhao, Z., Shi, H., Liu, Y., Zhao, H., Su, H., Wang, M., et al. (2014). The influence of duckweed species diversity on biomass productivity and nutrient removal efficiency in swine wastewater. Bioresource Technology, 167, 383-389. 